\title{
An Early Holocaust Novel: White's Riders in the Chariot, a Critique
}

\author{
JOHN DOCKER
}

\begin{abstract}
Patrick White's novel Riders in the Chariot (1961) can be regarded as a contribution to Holocaust literature, broadly defined. The novel features as one of its main characters Mordecai Himmelfarb, a Holocaust survivor, who makes his way from Germany, via Palestine, to Australia. In a comparison with Joyce's Ulysses, with its anti-essentialising construction of the complex consciousness of Bloom, Riders in the Chariot is revealed to be essentialising in its notions of Jewishness. It assimilates Jewish identity to a romantic discourse of attachment to land, highly problematic in a continent where the Indigenous people have been largely dispossessed of that land. The essay also discusses the novel's interest in Kabbalah. Overall, the essay convicts the novel of aesthetic crudity, which has troubling implications for how it perceives its characters, including Jewish characters.
\end{abstract}

'And so you killed the snake.'

'That is not killing,' said Mrs Jolley, propping the spade.

'That is ridding the world of something bad.'

'Who is to decide what is bad?' asked Miss Hare.

(Patrick White, Riders in the Chariot')

Mark Levene uses the above quotation as an epigraph to introduce The Rise of the West and the Coming of Genocide, the second volume of his long and eagerly awaited Genocide in the Age of the Nation State. ${ }^{2}$ Levene is signalling that the novel by Australia's Nobel Prize winning author Patrick White (1912-90), while well known in Australian literary history, is at last attracting attention as an early example of evocation of the Holocaust. Riders in the Chariot was published in 1961, the same year as the Eichmann trial in Jerusalem. ${ }^{3}$ An important character in Riders in the Chariot is Mordecai Himmelfarb, a Holocaust survivor, who makes his way from Germany, via Palestine, to Australia. The novel evokes the Holocaust, and constructs Jewish identity, in

Holocaust Studies: A Journal of Culture and History, Vol.13, No.2-3, Autumn/Winter 2007, pp.87-108 PUBLISHED BY VALLENTINE MITCHELL, LONDON

Copyright (C) 2007 Vallentine Mitchell 


\section{Electronic Offprint}

Himmelfarb's German upbringing, journey to and imprisonment in a concentration camp, his escape, his passage across the hemispheres, and his survivor life in the antipodes. So far, however, it seems to have escaped the attention of the critical literature concerning Holocaust novels. ${ }^{4}$

In part this inattention is the result of how Holocaust literature is defined. For example, David Patterson, Alan L. Berger and Sarita Cargas write in the preface to their Encyclopedia of Holocaust Literature that the authors selected for the volume 'survived the Holocaust, perished in the Holocaust, or were otherwise closely connected to the Holocaust', and nearly all of them are Jewish. The editors contend that what distinguishes Holocaust literature is that it is the 'work of witnesses', witnesses who have undertaken 'a literary response to the Holocaust'. For this reason, the editors have excluded second-generation authors as well as writers who have 'merely incorporated the Holocaust theme into a work' - such as William Styron, Thomas Keneally and Sylvia Plath - and who have 'no other direct link to the Holocaust'. ${ }^{5}$ Patrick White was not Jewish, nor was he connected to the Holocaust as witness and survivor. In these terms, White has 'merely incorporated the Holocaust theme into a work'.

Other critics argue that Holocaust literature is an inclusive, if always unstable, troubling, and controversial category that cannot be confined to witnessing by survivors or those closely linked to the Holocaust. ${ }^{6}$ In his preface to The Holocaust Novel, Efraim Sicher writes that most discussion of Holocaust writing starts from 'the premise that testimony provides a primary source for witnessing, and all that follows must be secondary, inferior, or discredited'. He goes on to caution, however, that memory can be 'notoriously fickle' and that survivors tend to remember partially or from perspectives limited to their personal experience. Memory is always reconstructed, mediated and filtered through 'subjective hindsight', and he reminds us that no story can be told without being reordered and emplotted: 'Imagination and fantasy do not necessarily impair authenticity. Fiction and history are not exclusive. Both, in fact, are narrative constructions.' Sicher suggests that those who write Holocaust novels are not always connected to Holocaust survivors, and that like the 'second generation', they imagine a world they have not personally experienced. Sicher also argues that the Holocaust novel cannot be defined as or confined to a specific genre; rather it bursts the 'already fuzzy' generic boundaries of autobiography and fiction, memoir and fantasy, historical document and realist novel. ${ }^{7}$

In this essay I will follow Sicher's inclusive approach in referring to

Copyright (C) 2007 Vallentine Mitchell 


\section{Electronic Offprint}

\section{AN EARLY HOLOCAUST NOVEL}

White's Riders in the Chariot as a novel that engages with the Holocaust and hence is broadly part of Holocaust literature. One of my aims, then, is to redress the neglect of Riders in the Chariot by a critical examination of its constructions of the Holocaust and Jewishness. Sicher concludes his preface by raising the question of literary quality, that any Holocaust novel must stand the test of whether it is good literature. ${ }^{8}$ I will state at the outset that I am not an admirer of Riders in the Chariot as a novel, and another aim of my essay will be to explain why I think certain aspects of the text are dubious, objectionable and, sometimes, offensive.

I shall quickly outline the narrative. When he arrives in Australia, the now elderly Himmelfarb, who had been a university lecturer in Germany, chooses to travel to the outskirts of Sydney, where he humbly takes up work in a factory making bicycle lamps. The factory is owned by Harry Rosetree, formerly known as Haï, who now wishes to be perceived and accepted as an assimilated migrant; he and his wife Shirl (once Shulamith) have converted to Christianity and attempt to lead ordinary suburban lives. By contrast, Himmelfarb is created as an outsider to Australian society, and we see him drawn to other outsiders who reside nearby: the eccentric Miss Hare, who lives in Xanadu, a decaying mansion she had grown up in and where she delights in the secret world of its wild garden (and where the conventionally minded Mrs Jolley is her housekeeper and would-be jailer); the kind-hearted fecund Mrs Godbold, a kind of earth mother at one with the eternal rhythms of procreation; and an Aboriginal artist Alf Dubbo, outsider by virtue of his Aboriginality and his art. The outsiders will often be mistreated, scorned, reviled, with Himmelfarb on one occasion being crucified by his fellow workers in the factory. Nevertheless, while strangers to the expectations of conventional society which they unwillingly antagonise, the outsiders form a kind of spiritual elite. The novel proceeds by constructing separate fictional biographies for each of them, as they come finally to connect and interact. They communicate, however, not by words or ordinary conversation, but by a kind of intuitive silence that recognises their shared fate as outsiders yet who also merit, by their being outsiders, a divine destiny. Himmelfarb, Miss Hare and Mrs Godbold are finally painted together by Alf Dubbo - recalling Ezekiel envisaging 'four living creatures' emerging from a holy whirlwind (1:3-6) - as riders in the chariot, blessed by God. ${ }^{9}$ Riders in the Chariot, like other post-war White novels, was recognised as challenging traditions of secular realism in the Australian novel. Rather than displaying any conventional plotting, Riders in the Chariot is anti-realist and metaphysical,

Copyright @ 2007 Vallentine Mitchell 


\section{Electronic Offprint}

working often through metaphor and image and an active narrator's observations and comments. The novel helped bring modernist writing to Australia while contributing to modernism worldwide..$^{10}$

It is also worth quickly sketching in Patrick White's biography. Born in Australia to a wealthy pastoral family, he chose not to continue his family's rural calling or to conform to what he saw as its stifling expectations of class and social behaviour; he was always attracted to those he recognised as outsiders and strangers, constituting a different kind of superior order, of sensibility, soul, spirit and imagination. ${ }^{11}$ He spent much of the 1920s and 1930s in London's writing and artistic circles, and was shaped by, and shaped himself in, the modernist literary movement. ${ }^{12} \mathrm{He}$ was also influenced by the prophetic and pantheistic traditions of English romanticism; indeed he crossed romanticism's optimism about the nearness of plenitude, of unity of spirit with nature, with modernism's hard edges, its apocalyptic sense of history as probable disaster.

There was, of course, no single modernist literary aesthetic, and in this essay I will touch on differences between Himmelfarb in Riders in the Chariot and Leopold Bloom in James Joyce's Ulysses, Bloom as perhaps modernity's most famous literary creation of a Jewish figure. ${ }^{13}$ Riders in the Chariot is an avowedly philosemitic novel, yet, disturbingly, I detect in phrases and images, and in interventions of its egregious narrator, attitudes more akin to the Judeophobia of another defining modernist text, T.S. Eliot's Gerontion. ${ }^{14}$

Joining the Royal Air Force, White spent much of the Second World War in Palestine, Greece and Egypt. ${ }^{15}$ In Alexandria, he met Manoly Lascaris with whom he would form a lifelong relationship, and they decided to live in Australia after the war. ${ }^{16}$ White's return to Australia after the Second World War was unusual; many intellectuals left in the 1950s for elsewhere (anywhere), regarding post-war Australian society as, impossibly and embarrassingly, politically conservative, censorious, narrow-minded, provincial, suburban, restrictive, racist, ethnocentric, unsophisticated, unurbane, uncosmopolitan, anti-intellectual, uninterested in the life of the mind; a society where the intellectual could not breathe and certainly was not given an assured place as remotely important; a society of ressentiment, where the intellectual should be brought into the many folds of conformity; a society where difference inspired fear and threat.

The White we observe in his letters and in David Marr's massive biography Patrick White: A Life is a writer who saw himself as a permanent outcast to mainstream Anglo-Australian society. In the tradition of artist as prophet, as saviour, he would attempt to use his art to raise its spiritual level.

Copyright (C) 2007 Vallentine Mitchell 


\section{Electronic Offprint}

AN EARLY HOLOCAUST NOVEL

Especially after his post-war return to this 'immense void of Australia' he felt driven, in a wonderful phrase, to 'fill the Australian vacuum'. ${ }^{17}$

\section{Riders in the Chariot}

In his biography Marr tells us that White spent the early 1930s almost untouched by European politics, unworried by fascism, and hardly aware of the fate of the Jews. Later, however, Marr says, White wished to make amends, particularly when living back in Australia. He now felt Jews were his fellows in exile, bringing European culture, sophistication and intensity to spiritually empty Australia. In the Castle Hill district on the edge of Sydney in the 1950s he and Manoly Lascaris got to know various Central Europeans and together they formed an outpost of Europe. Preparing to create the key character of Mordecai Himmelfarb for Riders in the Chariot, White began to study Judaism and the history of European Jews, and he was 'particularly keen to meet Jews'. The music of Bloch apparently helped him with Himmelfarb, for he had only to listen 'to know inside me what it means to be a Jew'. ${ }^{18}$

Riders in the Chariot, much of its action set in the philistine world of postwar suburban Sydney, is insistently structured in terms of a binary contrast: the unredeemed and the saved. On one side we observe with distaste the appalling surburbans themselves. In a dangerous chain of false being, the suburban host includes Mrs Jolley and her friend Mrs Flack - mother of the ringleader of the crucifixion of Himmelfarb in Rosetree's bicycle lamp factory - and indeed conventional respectability-seeking ladies of lower middle, middle, and upper middle class pretension generally. The chain extends to the mass of the horny-handed, female as well as male. When Himmelfarb is assaulted by his erstwhile colleagues, a group of drunken hands who had been celebrating a lottery win, they are eagerly encouraged by the women who work there in the office. Blue, the crucifixion party's leader, is somehow being controlled by, is the rough instrument of, the spirit of his mother Mrs Flack. In romantic and modernist terms, such characters belong to an external, practical, utilitarian world of superficial instrumental reason, using words as weapons, and they envy and wish to destroy those they feel are different, those they suspect possess a secret centre of true being, those who make them register their own, as it were, corelessness: 'To some it is always unendurable to watch the antithesis of themselves. ${ }^{19}$

The suburban host also, alas, now includes Himmelfarb's employer Harry Rosetree along with Shirl Rosetree as they attempt to conform to what they think are the norms of respectable conventional Australians. But assimilation is

Copyright (C) 2007 Vallentine Mitchell 


\section{Electronic Offprint}

hard if not impossible; they can never quite get it right, bringing their children up as Catholic in a largely non-Catholic area. Himmelfarb's face reminds Harry of 'the one great archetypal face' of his Jewish fathers. The factory owner recalls his childhood, when he was young Haïm and cherished religious tradition, knew the 'wisdom of the Torah and the teaching of the Talmud'. ${ }^{20}$

Just before his crucifixion Himmelfarb crosses Sydney Harbour by train and enters Harry and Shirl's home, situated in the wealthier suburbs where the Rosetrees try to blend into a life of 'ruthless materialism', of 'plastic ladies' and watering the lawn. Himmelfarb's sudden appearance is traumatic for Harry. Torn between his superficial social identity and his lost authentic Jewish essence, knowing always a 'latent misery', he breaks down, cries, and hangs himself. Shirl Rosetree is not, however, similarly moved. Shirl has lost her essence, that which she had been, Shulamith 'the black, matted girl' of her European past. She had never really loved Harry ('Mrs Rosetree had a secret longing for hard, blond men') and dedicates the rest of her life to trying ever harder to conform: 'She had a kind of gift for assimilation.' What were most important to her were the texture-brick home, the streamlined car, the advanced shrubs, the grandfather clock, the walnut-veneer radiogram, the washing-machine, and the mixmaster. ${ }^{21}$ Women, the reader of Riders soon realises, represent the worst and the best of earthly creatures.

On the other side, there is the struggle and pain of a spiritual elite, indifferent to material reward and social conventions and status, they who will eventually ride in the chariot of illumination but who meantime are trapped amongst the unworthy. Miss Hare is created as an Erdgeist, an earth spirit daily reborn in the womb and birth canals of nature, nature as dark busy organic activity, as growth, decay, death and new growth. ${ }^{22}$ Her friend Mrs Godbold lives not far away in a humble shed as a Gea-Tellus (as Mr Bloom in Ulysses in his final moments before sleep thinks of Molly) ${ }^{23}$ ever bountiful with children and loving-kindness. Also nearby Himmelfarb, their leader, messiah, saviour, prophet, an Elijah, lives in an unpretentious house. Alf Dubbo paints the ascension of this elite of spirit just before he dies, his life's work arriving at its fruition as it performs this act of homage.

How does Mordecai Himmelfarb manage to avoid becoming another Harry Rosetree? The prehistory of Himmelfarb as a European Jew is evoked at some length in Riders in the Chariot. Although Haïm Rosenbaum unhappily lapsed into Harry Rosetree, he was always haunted by the female voices from his childhood ('the voices of the dark women continued to vibrate inside him'). It is 'dark' female presence and wisdom which had saved Himmelfarb as he

Copyright (C) 2007 Vallentine Mitchell 


\section{Electronic Offprint}

AN EARLY HOLOCAUST NOVEL

grew up in Germany. Riders' narrator tells us that Mordecai was born in a north German town sometime in the 1880s. His father, Moshe, was a dealer in furs, and though the family had many kin connections with Jews from Eastern Europe and Russia, Moshe himself chose to identify with Germany and Western Europe, where Jews had been emancipated in the new age of Enlightenment and universal brotherhood. Moshe still went to synagogue, but regarded himself as a 'worldly Jew of liberal tastes', as 'the reasonable man'. Mordecai's father, then, has allowed himself to be seduced by an attachment to an 'outside world', a false Germany of apparent acceptance, culture ('the beauties of Goethe'), and prosperity. By contrast, Mordecai's mother felt that it was only in 'certain dark medieval streets' that she could escape from the oppressive material existence that so pleased her husband. The mother welcomed to their home cousins fleeing the pogroms back east, cousins 'orthodox' and 'dark' who embarrassed the father. The father will later convert to Christianity and leave the mother, his life declining into indifferent death as all around him, Christians and Jews, regard him with contempt. ${ }^{24}$

The son fortunately becomes increasingly drawn to his mother and her traditional values. Such was not clear at first or for many years, because Mordecai grew up a brilliant scholar, going to Oxford and returning to become a university teacher of English literature. But Mordecai as student and then academic increasingly senses the emptiness of the life of the mind, realises that 'reason is far too imperfect a weapon'. Living the life of reason means for Mordecai a 'shrivelling of the spirit in himself', that he had 'dried up'. He has to recover 'his faith' and the 'oil and spices of tradition' despite 'his rational self', and he effects this by studying mystical Kabbalistic texts and by drawing closer to the spirit of his mother. It finally becomes evident that his mother had 'given him her character', that he had been created out of the 'mother's silence and solitude of soul'. He rejects the spirit of his 'selfcongratulating father', absorbing his mother's spirit by non-rational means, 'through the tips of her fingers or subtler colloquy of souls'. A distant cousin the mother had once welcomed to their home when he was a child, the 'Galician rabbi' whose hands were 'almost womanly', comes to supplant Mordecai's father as spiritual guide. The woman Mordecai marries, Reha, is like his mother reborn, devout, uninterested in scholarly knowledge, 'homely', even myopic like his mother, and similarly disliking 'worldly practices'. Reha is an 'initiate' of 'mysteries' chiefly because of her very 'simplicity'. She is devoted to Mordecai; every night while he does his academic preparation she keeps him company, sewing or knitting for poorer

Copyright (C) 2007 Vallentine Mitchell 


\section{Electronic Offprint}

Jews. She is sure that he will become a saviour of his 'race' and of humanity, those Reha thinks of, including herself, as 'the ordinary ones'. She is privileged to keep him company on this part of his life's journey - 'with humility, conscious of the minor part she would be given to play'. ${ }^{25}$

Once Mordecai Himmelfarb has realised that he must go the way of his mother and Reha, of non-reason, he can strive for the simplicity and humility that accompany his fatedness as a saviour, a zaddik. It is a difficult and tragic journey that the narrator now has to trace for us in the midst of the Holocaust. Himmelfarb will lose Reha to the concentration camps; he himself will survive because of an uprising at the camp he is sent to, which allows him to drift with partisans in the forests and make his way to Palestine and eventually to Australia. It was expected by his conventional sponsors and advisers that as a former university professor he would apply for a post equal to his intellectual gifts. But Himmelfarb declares: 'The intellect has failed us.' He makes his way to the outskirts of suburban Sydney, 'the fringes of the city', away from any Jewish community or urban intellectual life, and here as if ordained he makes contact with Miss Hare and Mrs Godbold. After talking to Miss Hare and evoking his life's narrative, Himmelfarb tells her that she too is a redeemer, a 'hidden raddik', one of those who in each generation go secretly about the world 'healing, interpreting, doing their good deeds'. Himmelfarb and Miss Hare realise that they along with Mrs Godbold will become riders in the 'Chariot of God', zaddikhim not confined to Jews but redeemers of humanity. Miss Hare and Mrs Godbold are riders because, like Reha, such women possess an 'extreme simplicity of soul' existing at a deep level below 'words'. ${ }^{26}$

Throughout Riders the elect desire to share a communion of silence, since words are the instrument of repressive reason; each enjoys or strives for unity with nature, that which reason cannot understand or reach, and each possesses a secret core, an essence, of true being. I will particularly critique such essentialising in this essay.

\section{Jewish Identity, English Romanticism}

In Ulysses, Leopold Bloom's feelings concerning Jewishness are bafflingly elusive, decentred, palimpsestial, fantastical, parodying and self-parodying. Bloom rejects any confining unambiguous identity. How Bloomean is Mordecai Himmelfarb, he who submits with an expression 'almost of contentment' to crucifixion in Harry Rosetree's bicycle lamp factory? ${ }^{27}$ Is Himmelfarb an anti-Bloom?

Copyright (C) 2007 Vallentine Mitchell 


\section{Electronic Offprint}

AN EARLY HOLOCAUST NOVEL

Himmelfarb is constructed in Riders in the Chariot as embodying 'certain inherited truths'. He becomes a walking 'archetype', who would have 'shamed his apostate father'. In Australia, talking to Miss Hare, he presents himself as the essential Jew, the conscience of his people, wanderers who can only live in houses that are 'fragile and ephemeral': 'I am a Jew, you see.' He assumes that Jews are European. To Miss Hare he refers to himself as 'the Jew'. When he enters the Rosetrees' house, Shirl Rosetree sees Himmelfarb as representing the 'one Jew' of history. ${ }^{28}$

In this conception, identity has little to do with the 'outer man' that ordinary humans perceive. In his fragile house Himmelfarb humbly cherishes religious texts, and in such humility, unreachable by the arrogance of intellect, he comes ever closer to the 'centre of his being. ${ }^{29}$ 'This 'centre' of true Jewishness is in continuity with medieval Jewry (as was his mother) and with Eastern European and Russian Jewish experience. But it is not realisable by those Jews like his father who identify with the Enlightenment of Western Europe, and indeed Himmelfarb's own intellectual productions, as dutiful academic author of some literary critical analyses of mostly minor English literature, are derided in the novel.

Riders in the Chariot is a kind of riposte to Ulysses, for where Joyce's novel teases and revels in identities as plural, uncertain, slippery and opaque, Riders creates identity as the solemn reverse. Himmelfarb, having chosen not to go the way of Enlightenment Jewry, emerges as unified in his being, authentic, coherent, and certain of Jewish identity as religious, mystical, redemptive, messianic and traditional, organised around the 'certain inherited truths' that are apparently originary and should be telos for all Jews. ${ }^{30}$ Yet we can have our doubts about this unitary identity, doubts inspired by certain textual stresses in the novel, excesses of meaning that undo the Himmelfarbfriendly narrator's attempts to present Himmelfarb as archetypal. In particular, there are tensions in the novel between Himmelfarb as ideal Jew yet where Jewish identity, especially after Himmelfarb reaches Australia, is increasingly assimilated to certain inherited English romantic ideals.

Himmelfarb is follower as well as leader. In Europe he learnt from his mother and wife how to be a proper Jew, to observe the single true way. In Australia he learns from Miss Hare certain other originary truths: in Propp's terms, she is a donor in the narrative, appearing at a crucial time to provide the hero with vital information that permits him to become seeker and quester rather than victim and defeated. When Himmelfarb meets Miss Hare he tells her, under a canopy of tree branches, that Jews, confined within

Copyright (C) 2007 Vallentine Mitchell 


\section{Electronic Offprint}

ghettoes, were excluded from contact with the natural world. With the example of Miss Hare before him, he learns the reward of humble attention to nature, his core becoming, as he sits on his veranda at dusk, like 'some darker, greener flame'. While walking beside the 'green river' next to the factory, the water, in an epiphanic exchange, glistens for him, so that now a 'green effulgence ... emanated from, as much as it enveloped, him'. ${ }^{31}$ In terms of romantic neo-platonism, Himmelfarb's inner core harmonises with a universal order of Nature.

In Himmelfarb's journey towards true knowledge, Riders in the Chariot is romantic Bildungsroman. His opposition to Jews being attracted to Enlightenment reason blends with a romantic opposition to the Enlightenment and instrumental reason. Himmelfarb's learning to listen to the inner self formed by religious tradition and throw off his outer self of reason and intellect joins a romantic binary, of social surface as against true inner being: the romantic core constituted in exchanges with natural processes, the green world. When, in a moment of negative epiphany, Himmelfarb crosses by train the city and the Harbour Bridge and registers Sydney as life denying and distorting, as inferno, as the grotesque garish future unless humanity can be redeemed by those who know, his mood of millenarial anti-urbanism inherits not only early twentieth-century modernism but canonical English romanticism as in Blake and Wordsworth, not least those long anti-urban passages The Prelude stages in London. ${ }^{32}$ As with Wordsworth, there is in Riders a romance of the margins, valorising idiosyncratic characters - Miss Hare is a kind of Wordsworthian idiot woman or leechgatherer - existing apart from conventional superficial society.

\section{Jewish Identity, Aboriginal Australia}

What happens when English romantic concepts are transposed to a colonialsettler society like Australia? In a colonising way, Riders in the Chariot suggests that for those blessed by God and journeying towards God, where God (in pantheistic terms) is Nature, the passage can be smooth, direct and untroubled. Those touched with truth can, like Miss Hare and Himmelfarb, strive for a oneness with the antipodean natural world, a unity of whites with Aboriginal nature, whites who are the descendants of those who conquered, who dispossessed the Indigenous, whites who continue to be advantaged by that brutal dispossession. Indeed, in this romancing of the margins, the

Copyright (C) 2007 Vallentine Mitchell 


\section{Electronic Offprint}

AN EARLY HOLOCAUST NOVEL

white heroes of the narrative are themselves insistently evoked as 'dark', from the right kind of Jew in the old world to the chariot riders of the new. ${ }^{33}$

In Riders the margins are unified, so unified that their romantic possession of the natural world in Australia is accepted, sanctioned and celebrated by the novel's Aboriginal character. In one of his culminatory paintings Alf Dubbo, the 'solitary blackfellow', evokes Himmelfarb as 'the Jew-Christ', portraying Christ 'darker' than is usual in convention. When Dubbo paints Miss Hare as the Second Mary, he evokes her as like a 'ring-tail possum' in a 'dreamtime womb of transparent skin'. Riders happily permits an Aboriginal character to enfold certain white characters into his own land and mythology, his own 'dreamtime', his own chronotopes. Here is romantic desire grounded indeed in white mythology. It is, however, an interesting textual trace of a different history that Alf Dubbo should regard Miss Hare as not only like the indigenous possum but as 'fox-coloured', an image that whispers of contradictory signification, of invasion and predation. ${ }^{34}$

\section{Jewish Identity and Kabbalah}

As the narrative increasingly maps Jewish identity onto romantic axes and axioms, the proposition that Mordecai Himmelfarb embodies 'certain inherited truths' of Judaism begins to look increasingly curious. The true Jewish way apparently is to strive (like Miss Hare, Mrs Godbold, Alf Dubbo) to abjure intellect, reason and words, to choose and enjoin 'silence. ${ }^{35}$ Yet such striving by Himmelfarb stands not only as a rejection of eighteenth and nineteenth century discourses of Enlightenment but also of long Judaic traditions of textuality, of Judaism as a religion of the book, of words, of textual commentary, of interpretation and reinterpretation, of writing, intellect, mind.

Derrida in his essay 'Edmond Jabès and the Question of the Book' writes of a 'certain Judaism as the birth and passion of writing', that there is a 'pure and founding exchange' between 'the Jew and writing', and that the 'situation of the Jew becomes exemplary of the situation of the poet, the man of speech and of writing'. For the Jew as exile, as wanderer, the 'necessity of commentary, like poetic necessity, is the very form of exiled speech', resonances which, says Derrida, are also to be found in the Kabbalah. ${ }^{36}$ Ammiel Alcalay in After Jews and Arabs qualifies Derrida's argument here. Alcalay suggests that Derrida, in his writing on the poetry of Jabès, is not challenging the myth that the Jew is always pariah, outsider, wanderer and other, whose only house is that 'writing $=$ Jew $=$ Book'. For Alcalay, such a

Copyright (C) 2007 Vallentine Mitchell 


\section{Electronic Offprint}

view of 'the Jew' totalises European Jewish experience as universal. It ignores another long and rich cultural history, that of Moorish Spain, North Africa, the Mediterranean, the Levant - the Islamic Orient where for more than 1,000 years 'the Jew was native, not a stranger but an absolute inhabitant of time and place', in occupations of all kinds, in cultural and intellectual life, participating in the very poetics of heterogeneity that constituted the Levant's distinctiveness. And he argues that the writing of Jabès, originally from Egypt, still signifies even in exile in France the collective duration of that Levantine history. ${ }^{37}$ Alcalay disagreeing with Derrida's interpretation of Jabès' texts: such activity of writing, of movement of the word, Himmelfarb rejects in the name of an absolute and exclusive call to 'silence'.

Such a call to silence may indeed accord with Himmelfarb's supposed interest in Kabbalism. In The Essential Kabbalah Daniel C. Matt says of The Zohar, The Book of Radiance, that near the

top of the sefirotic ladder, meditation reaches Binah. She is called Teshwvah, Return. The ego returns to the womb of being. Binah cannot be held in thought. ... In the depths of Binah lies Hokhmah, Wisdom. The mystic is nourished from this sphere. Profound and primal, it cannot be known consciously, only absorbed. In the words of Isaac the Blind, one of the earliest kabbalists of Provence, 'The inner, subtle essences can be contemplated only by sucking, not by knowing'. Beyond Hokhman is the Nothingness of Keter, the annihilation of thought. In this ultimate sefirah human consciousness expands, dissolving into Infinity. ${ }^{38}$

Certainly there are affinities here with Himmelfarb and even more, perhaps, especially in the remarkable image of contemplation as sucking, with his friend and mentor Miss Hare. Yet the Kabbalists, as in the Book of Zohar, produced an immense body of writings. Himmelfarb's rejection of writing and his embracing of silence strike me as a strand of Kabbalah very much filtered through - assimilated to - English romantic discourses of desired moments of absorption in nature. ${ }^{30}$

\section{Jewish Identity and Visuality}

The Aboriginal artist Alf Dubbo paints Himmelfarb 'the Jew-Christ' as a 'flat, almost skimped figure, with elliptical mouth, and divided, canvas face'. ${ }^{40}$ Yet that Alf Dubbo should paint Himmelfarb at all, with the full approval of the narrator, is also curious in terms of the novel's claim to anchor Judaism

Copyright (C) 2007 Vallentine Mitchell 


\section{Electronic Offprint}

AN EARLY HOLOCAUST NOVEL

in 'certain inherited truths'. Judaism is very divided over the question of visual representation: there are no certain single truths, the inheritance is highly contradictory. In Exodus there is the injunction from God to Moses that there be no graven images; in particular, that there be no representation of God himself in figural form; Moses, on the other hand, is quite frequently in close visual contact with God. In Tractatus Theologico-Politics Spinoza sardonically points out that in many places in Scripture the injunction against visual representation does not hold, and God is often represented in highly anthropomorphic ways. ${ }^{41}$

Daniel Boyarin, in his essay 'The Eye of the Torah: Ocular Desire in Midrashic Hermeneutic', similarly argues that in the biblical texts and in later Rabbinic tradition there was an embracing of the visibility and corporeality of God. According to Rabbinic tradition, the moments in which God was held to have shown himself to the children of Israel were high points in Exodus, the crossing of the Red Sea and the giving of the Torah on Mt. Sinai. Boyarin notes that in Scripture one is not normally permitted to see God, and it may be dangerous to see God, and there is the taboo on images of God; but in Torah God most certainly can be seen and is seen. The memory of having enjoyed the sight of God in the Bible and the desire to have that experience again, Boyarin suggests, were a vital part of the study of Torah and making of midrashic commentary in Rabbinic religion. By the adoption of a hermeneutic method, the Rabbis hoped to recover the historical memory and original visions of God enacted in the Bible; a hermeneutic of recollected experience and visual perception, erotically charged. ${ }^{42}$

There is also the erotically charged Jewish mystical tradition, often drawing strength from the Song of Songs as well as the first chapter of the Book of Ezekiel, where the narrator begins by telling us 'the heavens were opened, and I saw visions of God' (Ezekiel 1: 1); and such reaching towards visions of God was certainly important in the medieval Kabbalists. ${ }^{43}$

Riders in the Chariot follows this mystical and Kabbalistic tradition, with its four riders in the chariot, as in the book of Ezekiel. ${ }^{44}$ Himmelfarb 'the JewChrist' is painted as a 'figure'. Such visual representation is to be seen, Riders implies, as consonant with the only kind of Judaism that is proper, that of the Eastern European and Russian Jews and especially of the 'Galician rabbi', who inherited the medieval tradition cherished by Himmelfarb's mother.

Yet is the history of Judaism - as Daniel Boyarin says, the very name 'Judaism' is a 'reified fiction of four thousand years of a culture ${ }^{45}-$ so

Copyright (C) 2007 Vallentine Mitchell 


\section{Electronic Offprint}

100 HOLOCAUST STUDIES: A JOURNAL OF CULTURE AND HISTORY

simple, so uncomplicated, so uncontradictory that there should be only one proper way?

\section{The Shtetl}

Should Eastern European Judaism be so innocently idealised as it is throughout Riders in the Chariot? In The Non-Jewish Jew, in the essay on Marc Chagall, a Russian Jew brought up in a shtetl and the great forerunner of Surrealism and Expressionism, Isaac Deutscher argues that 'Judaism's hostility towards the visual arts is notorious', and that rabbinical orthodoxy 'stunted' their growth 'far more cruelly than even Calvinism did'. The shtetl, the little town within the Jewish pale of Eastern Europe, would have its cantors and musicians, its bards, poets, and composers of folk tales; but it had 'no painters or sculptors'. Even the nineteenth century Hassidic revolt against Talmudic scholasticism, Deutscher feels, did not weaken the millennia-old abhorrence of the graven image, and Hassidic revivalism in any case quickly ossified into another rabbinical orthodoxy. It was 'in defiance of tradition', outside of the Synagogue (whose walls were 'bare and grim'), that the Russian or Polish Jew would paint. In and through Chagall, the 'long suppressed visual imagination of the Jew burst out like a volcano exploding in rainbows', ${ }^{46}$

In Riders in the Chariot the narrator suggests that the traditional Jewish world of Eastern Europe, its present representative the 'Galician rabbi' whose hands were 'almost womanly', is a single world, unified across time (except for those Jews seduced by wealth who would migrate to contemporary America to absorb themselves in its 'nylon dream'). ${ }^{47}$

Deutscher's The Non-Jewish Jew, calling attention to 'rabbinical orthodoxy', proposes otherwise, suggesting histories and stories of tension and conflict, of intolerance towards alternative identities. Deutscher's own ancestors, so Tamara Deutscher tells us in the introduction, came in the sixteenth century from Nuremberg to Galicia. Mainly printers, they originally bore the name of Ashkenazy. Isaac was named after his great-grandfather, a learned Talmudic scholar, a man of frightful temper and fanatic convictions, who became enraged that his son had turned to Hassidism, with its more joyous view of life and more lax discipline; he had his son persecuted by the non-Jewish authorities. In later generations, however, the family became Hassidic. When, nevertheless, Deutscher's own father wrote a history of the Jews in Germany, based on years of research, the manuscript was thrown into the fire by his father's mother, fearing that it might be heretical..$^{48}$

\section{Copyright (C) 2007 Vallentine Mitchell}




\section{Electronic Offprint}

AN EARLY HOLOCAUST NOVEL

In Arnold Zable's autobiographical Jewels and Ashes (1991), the Australian narrator writes of his return to ancestral sites in Poland, meeting the few Jews who survived Nazism in Bialystok and surrounding towns, places still imbued with traces of shtetl life for centuries. He hears stories of resistance to Nazi occupation forces and of the partisans in the forests: here Jewels and Ashes joins with Riders in the Chariot in disputing a narrative like Steven Spielberg's 1993 film Schindler's List that constructs Polish Jews as passive during the Holocaust. He meets and talks to Jews who appear desperate to escape from the confinement of small-town life and envy his diaspora state, growing up the other side of the world in a Yiddish-speaking community in Melbourne. The narrator, however, yearns to consecrate the memory of traditional Jewish life in pre-Second World War Poland as warm, spontaneous, cooperative, collective. At the same time he knows his own 'dream of the shtetl' is a 'fragile romance', and he recalls other stories, of his great-grandparents attempting to negotiate ancient quarrels that still simmered in the towns and hamlets of the pale; in particular the bitter conflict between older austere traditions of pious study and strict discipline, and, in the 1700s, the newly emergent Hassidic movement, with its emphasis on devotion, dance, and wonder-workers. The quarrel had split shtetl communities apart, and there were bans, book burnings, family feuds, denunciations to the czarist authorities resulting in imprisonment; marriage to Hassidim and assistance at their burials had been forbidden. ${ }^{49}$

In Riders Mordecai's father Moshe welcomes emancipation in Western Europe: it heralds that 'the Jewish soul was at last set free', that the 'walls were down, the suffocating rooms were burst open, the chains of observance had been loosed' ${ }^{50}$ But this whisper in the text, these suggestions of attempts to destroy dissent and difference within Eastern European Jewish history, have to contend with the crushing portrait of Moshe as contemptible in his delusions about enlightened Germany. By contrast, (supposed) Jewish tradition in Eastern Europe is admired in a fundamentalist way.

In 'Edmond Jabès and the Question of the Book' Derrida contrasts two kinds of interpretation as irreducibly different, that between the poet welcoming the 'adventure of the text', and the rabbi insisting on exegesis as Law. ${ }^{51}$ In these terms, Mordecai Himmelfarb clearly becomes rabbi not poet; he is uninterested in the play of interpretation and any loosening of a particular kind of Jewish identity. He insists on representing himself as the true way, as archetypal, and he is disturbingly authoritarian in his relations with Harry Rosetree, like his father in his eyes an apostate. Himmelfarb

Copyright (C) 2007 Vallentine Mitchell 


\section{Electronic Offprint}

102 HOLOCAUST STUDIES: A JOURNAL OF CULTURE AND HISTORY

refuses to accept Harry Rosetree's new identity ('We are Australians now'). In the factory Himmelfarb had already felt called upon to address Rosetree as Rosenbaum, and tried to get him to speak German with him and to admit he was Jewish - 'Surely you are one of us'. For all that Himmelfarb submits almost with 'contentment' to the crucifixion in the factory, and although he desires humility and simplicity, we see him hunting Harry Rosetree to his home, and, in a kind of stalking epistemic violence, refusing to Rosetree the dignity of choice, that Rosetree or anyone else's identity could be - as suggested throughout Ulysses - fragmented, contradictory and unknowable. ${ }^{52}$

\section{That Narrator}

In Problems of Dostoevsky's Poetics Mikhail Bakhtin, contrasting Tolstoy and Dostoevsky, argues that in Tolstoy's fiction the author dominates his texts in a monologic way, is all-knowing and all-controlling. ${ }^{53}$ Here again Riders in the Chariot emerges as a kind of essentialising riposte to Uhysses. Where in Ulysses narration in a dialogic way is multiple and mysterious, Riders offers the perspectives of a single all-seeing narrator, whose knowledge of every character is exhaustive and complete. In Riders we are told that suburbia as in Mrs Flack and Mrs Jolley 'took for granted its right to pass judgement on the human soul, and indulge in a fretfulness of condemnation'. ${ }^{54}$ Yet if the narrator, masculinist and aggressive, omnipresent and omniscient, omnipotent and omnivorous, does not like this or that character, those who fall on the wrong side of the binary divide of elect and non-elect, he will pursue and pursue them until revenge is enacted.

Throughout Riders the narrator himself is fretfully condemnatory, inducing a cumulative crudity of aesthetic effects. In particular, the narrator is unable to resist a dismissive damning mode, as in the continuous references to 'plastic ladies', accompanied by physical disparagement. ${ }^{55}$ When Miss Hare was a child, her mother's lady friends, faced with oddity, knew 'firmly to suppress, like wind in company, the rise of unreason in their minds'. Mrs Jolley passes her tongue 'along her stripped lips'; eating, her face becomes a 'series of lumps'. When Himmelfarb's father Moshe marries a young Christian woman, Christel Schmidt, her hair is as 'heavy and yellow in its snood as horses' dung'; she is kind and capable, but 'of no further significance'. When Moshe dies 'of his young wife', he is buried 'by a priest with a stammer, and an acolyte with a cold'. A young German soldier stands 'holding a gun, and picking his nose'. On the train to the concentration camp, when Himmelfarb talks to a formerly

\section{Copyright (C) 2007 Vallentine Mitchell}




\section{Electronic Offprint}

AN EARLY HOLOCAUST NOVEL

wealthy Jewish woman, the Lady from Czernowitz, we learn of her 'floury breasts', though a little later we see that she has 'one dug'. When Himmelfarb arrives in Palestine, his brother-in-law Ari tries to convince him to stay and join the Zionist enterprise. In the exchange between Ari and Mordecai, Ari looks like he is 'trying to rid himself of phlegm' as he 'fidgeted about on his broad behind'. At Rosetree's Brighta Bicycle Lamps factory, the machinery 'hissed and pissed': 'Toothless lads hawked up mirthless laughter'. The men are 'pursy', or will loudly 'fart', while the ladies who work on the assembly line 'eased their plastic teeth' or 'shifted gum'.

When Himmelfarb confronts Rosetree over Jewish identity, Rosetree is 'not only mentally distressed', he can 'not detach the pants from around his groin'. Talking of Himmelfarb to his wife, Rosetree 'had to belch'. Mrs Flack or Mrs Jolley at times would 'stare dreamily into her own bottomless mind, watching the cotton-wool unfurl'. Like Mrs Jolley, Mrs Flack can draw back 'her strips of palest lips'; or she will hiccup. At the end of a conversation with her friend, Mrs Jolley was 'perspiring uncomfortably behind the knees'. When Mrs Godbold, then Ruth Joyner, was young, she worked as a maid for Mrs Chalmers-Robinson, who might hold a lunch for ladies 'wearing monkey fur'; they quickly become 'monkey-ladies', or 'sick, drooping monkeys'. Ruth sees her mistress without clothes, the lady appearing like 'the sac of a slack, sick spider'. Later we see Mrs Chalmers-Robinson at lunch at a restaurant with another lady, Mrs Colquhoun, a 'stream of melted ice-cream' threatening to 'spill from one corner of what had been' the latter's mouth. In the brothel scene one of the customers, Fixer Jensen, 'stood and picked his nose as usual'. Mrs Pask, Alf Dubbo's superficial foster mother, had on occasion to master 'her wind'. As the train passes through Sydney where the city's neon lights are a 'syrup' colouring the 'pools of vomit and the sailors' piss', Himmelfarb observes 'blue-haired grannies' whose breasts 'chafed to escape, from shammy-leather back to youth, or else roundly asserted themselves, like chamberpots in concrete'. ${ }^{57}$

In the factory, when news of the lottery win by the men gets abroad, Ernie Theobalds the foreman laughed 'as he played with the hair of his armpits'. When Himmelfarb is crucified by the drunken men led by Mrs Flack's Blue, Blue is so drunk the 'beer was running out of his navel'. Ernie Theobalds comes out to take a look, 'exploring the flesh under his singlet'. The policeman called to investigate is named 'Constable McFaggott'. While Alf Dubbo is on a bus, the conductor begins to 'clean his ears with a key'. When Dubbo dies, a bored young doctor is called, 'who was reading a

Copyright (C) 2007 Vallentine Mitchell 


\section{Electronic Offprint}

104 HOLOCAUST STUDIES: A JOURNAL OF CULTURE AND HISTORY

detective story, and scratching himself through his flies' ${ }^{58}$ Such writing is tedious, tiresome, and unworthy. The judgement of the Australian poet A.D. Hope, a contemporary of White's, on White's writing as 'pretentious and illiterate verbal sludge' has considerable continuing merit. ${ }^{59}$

So judging and bludgeoning is the narrator that, in relation to Jewish characters he despises for not being truly Jewish, for not being graven in the image of Himmelfarb, he also cannot resist physical disparagement. When Nazi soldiers guard Himmelfarb's group of Jews before they enter the train, one guard 'inserted the blade between the great buttocks of a fat Jew'. We are to understand this as the Nazi guard's brutal perception, yet how different is this formulation from the narrator's notation of Himmelfarb's brother-in-law Ari in Palestine 'trying to rid himself of phlegm' as he 'fidgeted about on his broad behind'? There is the reference to the Lady of Czernowitz having 'one dug' that 'hung down beside the ancient scar which represented the second'. On the way to Palestine, there is a 'Jewess' supervising distribution of clothing, who 'wore a moustache', where 'little points of perspiration were clearly visible on the hairs'. In Jerusalem Himmelfarb runs into Appenzeller, someone he knew from student days, a physicist, a 'coarse-skinned, bristly individual' who 'laughed at his joke, and the pores round his nostrils oozed'. Indeed, we learn that advice would 'swim from Appenzeller's skin, of which the pores had always been conspicuously large'. ${ }^{60}$ Such language is, I think, perilously close to the antisemitic, to Judeophobia.

Riders' narrator is not only Eastern European-centric about Jewish identity, but also Orientalist in relation to Palestine and the Levant. The narrator does not question the right of European Jews to colonise the 'stony soil' of Palestine, 'the Land', Jews who 'resisted the elements because there, at last, it was natural to do so': 'For the Jews were at last returning home. They would recognize the stones they had never seen, and the least stone would be theirs.' Ari and his sabra wife Rahel on their kibbutz 'belonged to their surroundings, like the stones, or the olive tree beneath which they were sitting'. The Arabs of Palestine are, however, almost invisible to the narrator, except for a 'couple of Arabs' who 'laughed' at Himmelfarb in Jerusalem: the Indigenous people of the land of Palestine are not evoked as belonging to its stones and olive trees; rather they are dismissed in a single contemptuous phrase. $^{61}$

Nevertheless, Himmelfarb refuses to stay in Palestine. Himmelfarb perceives Ari as 'dangerously arrogant'. He feels that the Zionist focus on the 'National Home', on 'force', and 'work' as 'the panacea', ignores soul and

Copyright (C) 2007 Vallentine Mitchell 


\section{Electronic Offprint}

AN EARLY HOLOCAUST NOVEL

spirit. Rahel the sabra already strikes Himmelfarb as merely 'practical'. ${ }^{2}$ Here, then, is a similarity with Ulysses, in the way Leopold Bloom opposes Zionist nationalism, though Bloom thinks of the Levant, and especially Jerusalem, as proudly Oriental. ${ }^{63}$

\section{Conclusion}

Reading Riders in the Chariot this time, it struck me as a rather odious text, not least in being dominated by a narrator who is all too similar to Foucault's panopticon: that which sees and surveys all, but cannot itself be seen; positions itself beyond reflexive scrutiny, beyond the remotest self-parody. In Riders narration is a discourse of certainty, a relentless gaze that everywhere passes 'judgement' on the 'significance' of each 'human soul' that comes before it for sentencing.

The utopianism of Riders is rather chilling. In its final narrative segment there is not just a permanent opposition of two kinds of being, clearly inferior and superior. There is also an optimism about society as capable of change, where Himmelfarb has indeed proven a redemptive Jew-Christ. In these prefigurations of utopia, Mrs Godbold's earth-mother loving-kindness lives on in her daughter Elsie and Elsie's husband Bob Tanner. New ideal Australians are emerging, with Elsie as another earth mother, and Bob, an ordinary young Australian male, infused with a female spirit of lovingkindness; the loving-kindness that has its own lineage, in Himmelfarb's mother, his wife Reha, Miss Hare, Mrs Godbold, and now Mrs Godbold's daughter.

What a philistine Utopia this promises to be! It will be anti-intellectual, since Enlightenment values of reason have apparently failed absolutely: the brushstrokes that belittle Jews influenced by the Enlightenment as well as Enlightenment ideals in general are themselves derisorily crude.

It has always struck me as curious that White's writing has been so admired for so long. Criticism in Australia tends to construct literary history as a narrative of progress, with White as a pinnacle, a beacon. ${ }^{64}$ But I cannot see White as a hero of Australian literary development, or of world literature. In terms of essentialising conceptions of ethnicity and identity, there is no vast difference between White's writing and the writings of Matthew Arnold and a host of English and European authors in the nineteenth century guided by a delusive obsession with relating culture to presumed ethnic essences. White's 1981 autobiography Flaws in the Glass: A Self-Portrait, for

Copyright (C) 2007 Vallentine Mitchell 


\section{Electronic Offprint}

example, relishes a language of ethnic and racial insult, particularly towards those - Turks, Orientals generally, Slavs, Germans - he sees as threatening the true and essential character and traditions of the peoples he admires. ${ }^{65}$ Criticism would do well to cease continuous celebration, and subject White's writings to searching critique. ${ }^{66}$

In these terms, I think Riders in the Chariot, as an early contribution to Holocaust literature, is certainly interesting, but also seriously flawed.

\section{NOTES}

1. Patrick White, Riders in the Chariot (1961; Harmondsworth: Penguin, 1964), p.83.

2. Mark Levene, Genocide in the Age of the Nation State, 2 vols. (London: I.B. Taurus, 2005).

3. I gain no sense from White's published letters, however, that he was interested in the capture of Eichmann and subsequent trial. See David Marr (ed.), Patrick White: Letters (London: Jonathan Cape, 1994).

4. There is, for example, no mention of Riders in the Chariot in Jacob Glatstein, Israel Knox and Samuel Margoches (eds.), Anthology of Holocaust Literature (1968; Philadelphia: The Jewish Publication Society of America, 1969) or in Lawrence L. Langer, The Holocaust and the Literary Imagination (1975; New Haven, CT: Yale University Press, 1977). In his introductory comments to the section 'Chariots' of White's letters for the period December 1958-February 1961, Marr notes that in Riders of the Chariot White, 'writing fifteen years after the revelations of Auschwitz ... was one of the first novelists to come to grips with this century's innovation in horror': Patrick White: Letters, p.151.

5. David Patterson, Alan L. Berger and Sarita Cargas (eds.), Encyclopedia of Holocaust Literature (Connecticut: Oryx Press, 2002), pp.ix-xi.

6. See the very interesting book by Sue Vice, Holocaust Fiction (London and New York: Routledge, 2000), which focuses on scandals concerning the Holocaust novels of Martin Amis, D.M. Thomas, Jerzy Kosinski, William Styron, Thomas Keneally and Helen Darville; in the conclusion on pp.163-4 there is discussion of Binjamin Wilkomirski.

7. Efraim Sicher, The Holocaust Novel (New York and London: Routledge, 2005), pp.xii-xiii, xviii, xxi.

8. Ibid., p.xxiii.

9. Concerning Ezekiel, cf. Karen Armstrong, The Great Transformation: The Beginning of Our Religious Traditions (New York: Knopf, 2006), pp.172-4.

10. Cf. John Docker, Australian Cultural Elites (Sydney: Angus \& Robertson, 1974).

11. In his letters White reflects that in his conception of Himmelfarb in Riders in the Chariot "what helped me most was the fact that throughout my life I have been an outcast myself'. See letter to his American publisher Ben Huebsch, Marr (ed.), Patrick White: Letters, p.180.

12. See White's autobiography Flaws in the Glass: A Self-Portrait (London: Penguin, 1981).

13. See John Docker, 1492: The Poetics of Diaspora (London: Continuum, 2001), chs.4-7.

14. Cf. Maud Ellmann, 'The Imaginary Jew: T.S. Eliot and Ezra Pound', in Bryan Cheyette (ed.), Between 'Race' and Culture: Representations of 'the Jew' in English and American Literature (Stanford, CA: Stanford University Press, 1996), pp.84-93.

15. David Marr tells us that in the Second World War White, having joined RAF Intelligence, spent the winter of 1943-44 in Palestine interrogating refugees to find targets to bomb in the German towns from which they had fled. See Patrick White: Letters, p.55.

16. John Rickard, 'Clark and Patrick White', in Carl Bridge (ed.), Manning Clark: Essays on his Place in History (Melbourne: Melbourne University Press, 1994), pp.47-8.

\section{Copyright (C) 2007 Vallentine Mitchell}




\section{Electronic Offprint}

17. David Marr, Patrick White: A Life (Sydney: Random House Australia, 1991), pp.312, 337. Cf. my review in Australian Historical Studies, Vol.99 (October 1992).

18. Marr, Patrick White, pp.225, 227, 332, 491, 523, 612

19. White, Riders in the Chariot, p.402.

20. Ibid., pp.202-4, 376-7.

21. Ibid., pp. 382, 386-7, 402-3, 447, 450, 483.

22. Concerning Miss Hare as Erdgeist, see Marr (ed.), Patrick White: Letters, pp.153, 196.

23. James Joyce, Ulysses (1922), intro. and notes by Declan Kiberd (London: Penguin, 1992), p.870.

24. Riders, pp.96-9, 104, 115-16, 205.

25. Ibid., pp.96-7, 99, 103-4, 110, 113, 116, 123, 125-6, 129-30, 136, 140-42, 427.

26. Ibid., pp. $97,154-5,198-9,308,427$.

27. Ibid., p.409.

28. Ibid., pp.91, 144, 301, 307, 383-4, 387.

29. Ibid., pp.194, 198-9.

30. Ibid., p.387.

31. Ibid., pp.89, 197, 205.

32. The romantic and modernist trope of the city - in particular, London - as anti-life continues in W.G. Sebald; see Austerlitz (2001; London: Penguin, 2002), pp.48-50.

33. Riders, pp.99, 131.

34. Ibid., pp.434, 454-6.

35. Ibid., pp.22, 37, 99, 135-6, 169, 187, 311, 434.

36. Jacques Derrida, Writing and Difference, trans. and intro. Alan Bass (Chicago: University of Chicago Press, 1978), ch.3, 'Edmond Jabès and the Question of the Book', pp.64-7, 74.

37. Ammiel Alcalay, After Jews and Arabs: Remaking Levantine Culture (Minneapolis: University of Minnesota Press, 1993), pp.1, 64-5, 67-71, and passim.

38. Daniel C. Matt, The Essential Kabbalab: The Heart of Jewish Mysticism (San Francisco: HarperCollins, 1994), Introduction, p.11.

39. Gershom G. Scholem, Major Trends in Jewish Mysticism (New York: Schocken Books, 1954), Ninth Lecture, 'Hasidism: The Latest Phase', pp.325-50, evokes the history of Polish and Ukrainian Hasidism of the eighteenth and nineteenth centuries, its transforming of Kabbalistic tradition into an accessible and popular movement, and its offering of a new kind of leader, a prophet, an illuminate, a saint-mystic, blessed with charisma, as in the figure of the Zaddik. In Scholem's view, Hasidism, while being very creative in terms of its religious energy, offered no new religious or mystical principles and ideas in terms of the history of Kabbalism.

40. Riders, p.456.

41. Baruch Spinoza, Tractatus Theologico-Politicus, trans. Samuel Shirley, introd. Brad S. Gregory (Leiden: E.J. Brill, 1989), pp.70-72, 228, 233.

42. Daniel Boyarin, 'The Eye in the Torah: Ocular Desire in Midrashic Hermeneutic', Critical Inquiry, Vol.16 (1990), pp.532-50; in this essay Boyarin critiques the view that Judaism is the religion in which God is heard but not seen. Martin Jay notes, in Downcast Eyes: The Denigration of Vision in Twentieth-Century French Thought (Berkeley: University of California Press, 1993), pp.14-15, 549-50, that recent scholarship suggests that there is a tension in Jewish history between iconic and anti-iconic tendencies, and that at various times and places there were images of cherubim, funeral paintings, and synagogue decorations, and also iconic representation in the textuality of the late Kabbalah.

43. For the Song of Songs see Boyarin, 'The Eye in the Torah', pp.541-44; on p.534 note 5 Boyarin points to the continuity of Rabbinic tradition and the medieval Kabbalists in terms of embracing God's visibility and corporeality. Cf. Gershom Scholem, Origins of the Kabbalah, ed. R.J. Zwi Werblowsky, trans. Allan Arkush (Princeton, NJ: Princeton University Press, 1990), pp. $238-44$.

44. Cf. Peter Beatson, The Eye in the Mandala. Patrick. White: A Vision of Man and God (London: Paul Elek, 1976), pp.111-13, 159-65.

Copyright (C) 2007 Vallentine Mitchell 


\section{Electronic Offprint}

45. Boyarin, 'The Eye in the Torah', pp.532-3.

46. Isaac Deutscher, The Non-Jewish Jew (London: Oxford University Press, 1968), ch.8, 'Marc Chagall and the Jewish Imagination', pp.155-6. I think that the massive involvement of Jews in the fantastical visual excess of Hollywood is also a release of the repressed; cf. Patricia Erens, The Jew in American Cinema (Bloomington: Indiana University Press, 1984).

47. Riders, p.143

48. Deutscher, The Non-Jewish Jew, introduction by Tamara Deutscher, pp.3-4. Cf. Israel Shahak, Jewish History, Jewish Religion (London: Pluto Press, 1994), pp.14-20; John Docker, 'Orientalism and Zionism', Arena, Vol.75 (1986), pp.88-91. Cf. also E.J. Hobsbawm, 'Homesickness', London Review of Books, 8 April 1993, p.20: 'It is easier to sentimentalise the shtetl now that it no longer exists than it was when young men and women had to live in it.'

49. Arnold Zable, Jewvels and Ashes (Melbourne: Scribe, 1991), pp.67-8, 91, 96, 100, 105, 144, 161-2.

50. Riders, p.98.

51. Derrida, 'Edmond Jabès', pp.67-8.

52. See Docker, 1492: The Poetics of Diaspora, pp.85-6. In Patrick White: A Life, pp.145, 151, David Marr tells us that when young, in 1936, White read Uysses and admired its technique, especially the way the author switches at will from the mind of one character to another, drifting with their thoughts; indeed, says Marr, Joyce became White's God and Ulysses his Bible. My argument, however, is that the essentialising of identity in Riders in the Chariots is the reverse of the antiessentialising of Ulysses in the construction of Bloom.

53. Mikhail Bakhtin, Problems of Dostoevsky's Poetics (Manchester: Manchester University Press, 1984), pp.47-75.

54. Riders, p.211.

55. Ibid., p.382. In this aspect Riders' narrator reminds me of the egregious narrator of Peter Carey's Oscar and Lucinda (London: Faber and Faber, 1988).

56. Riders, pp.32, 77, 81, 120, 129, 169, 178, 184, 192, 200, 206, 216.

57. Ibid., pp.203, 210, 212, 246-7, 250, 282, 334, 391-2, 468, 484.

58. Ibid., pp.401, 405, 416, 424, 435, 460.

59. The phrase from Hope's review of The Tree of Man in the Sydney Morning Herald, 16 June 1956, is quoted in Hu Wenzhong, 'The Myth and the Facts: A Reconsideration of Australia's Critical Reception of Patrick White', Australian Literary Studies, Vol.16, No.3 (1994), p.335.

60. Riders, pp.175, 184, 189-90, 192

61. Ibid., pp.143, 187, 189, 191-2.

62. Ibid., pp.191, 193.

63. Cf. Docker, 1492: The Poetics of Diaspora, pp.66-8, 74, 77-8.

64. Cf., however, Simon During, Patrick White (Melbourne: Oxford University Press, 1996).

65. From David Marr's biography we learn that White's life had taken, by the time Riders in the Chariot was published, 'a new course and he was dispersing his Jewish friends'. He wished, in the early 1960 s, to return to writing for the theatre. White now spoke of his old Central European Jewish companions as millstones. He broke with them 'brutally', justifying it on the grounds that he was an artist. Marr, Patrick White: A Life, pp.383-4, 455.

66. Cf. John Docker, 'Romanticism, Modernism, Exoticism: Patrick White in Biography and Autobiography', Southern Review, Vol.26, No.3 (1993), pp.358-76; 'White Mythologies: Ethnicity and Identity in White and Joyce', Proceedings of the Sixteenth Annual Conference, Association for the Study of Australian Literature, 1994 (Canberra: Dept. of English, ADFA, 1995), pp.207-13; 'How Close Should Writers and Critics Be?' Australian Book Review, No.202 (July 1998), pp.25-6. 